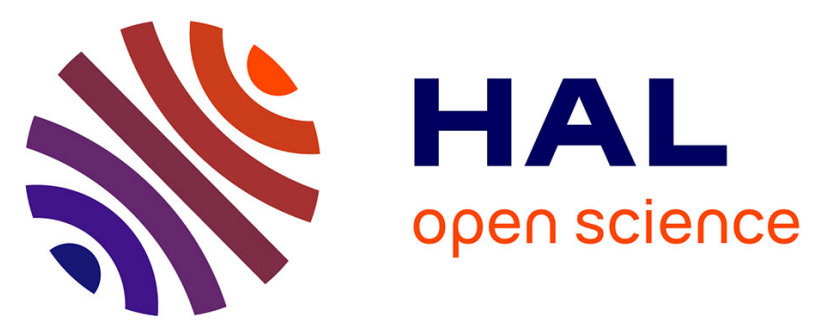

\title{
First efficient synthesis of SF 5 -substituted pyrrolidines using 1,3-dipolar cycloaddition of azomethine ylides with pentafluorosulfanyl-substituted acrylic esters and amides
}

Ewelina Falkowska, Vincent Tognetti, Laurent Joubert, Philippe Jubault, J.-P. Bouillon, Xavier Pannecoucke

\section{To cite this version:}

Ewelina Falkowska, Vincent Tognetti, Laurent Joubert, Philippe Jubault, J.-P. Bouillon, et al.. First efficient synthesis of SF 5 -substituted pyrrolidines using 1,3-dipolar cycloaddition of azomethine ylides with pentafluorosulfanyl-substituted acrylic esters and amides. RSC Advances, 2015, 5 (9), pp.68646868. 10.1039/c4ra14075c . hal-01149543

\section{HAL Id: hal-01149543 \\ https://hal.science/hal-01149543}

Submitted on 7 May 2015

HAL is a multi-disciplinary open access archive for the deposit and dissemination of scientific research documents, whether they are published or not. The documents may come from teaching and research institutions in France or abroad, or from public or private research centers.
L'archive ouverte pluridisciplinaire HAL, est destinée au dépôt et à la diffusion de documents scientifiques de niveau recherche, publiés ou non, émanant des établissements d'enseignement et de recherche français ou étrangers, des laboratoires publics ou privés. 


\section{COMMUNICATION}

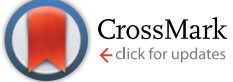

Cite this: RSC Adv., 2015, 5, 6864

Received 7th November 2014 Accepted 17th December 2014

DOI: $10.1039 / c 4 r a 14075 c$

www.rsc.org/advances

\section{First efficient synthesis of $\mathrm{SF}_{5}$-substituted pyrrolidines using 1,3-dipolar cycloaddition of azomethine ylides with pentafluorosulfanyl- substituted acrylic esters and amides $\uparrow$}

\author{
Ewelina Falkowska, Vincent Tognetti, Laurent Joubert, Philippe Jubault, * \\ Jean-Philippe Bouillon* and Xavier Pannecoucke
}

For the first time, di-, tri- and tetrasubstituted pentafluorosulfanylated pyrrolidines have been efficiently synthetized via 1,3-dipolar cycloaddition. In the case of tetra-substituted pyrrolidines, an unusual mixture of $1 / 1$ regioisomers was obtained. Theoretical calculations have been carried out and the regioselectivity has been explained compared to the results previously obtained in the trifluoromethylated pyrrolidine series.

The chemistry of organofluorine compounds is a rapidly developing research area due to its wide range of applications in a number of important fields such as drug discovery, materials sciences and agrochemistry. ${ }^{1}$ This particular interest in fluorine chemistry is due to the physicochemical characteristics of fluorine atom, including its small size and high electronegativity. In particular the presence of this atom in organic molecules affects their properties such as conformation, acidity/ basicity of the neighbouring functional groups, enhanced metabolic stability and increased lipophilicity. ${ }^{2}$ As a consequence, intensive efforts have been devoted to the development of original methods for the introduction of one or two fluorine atoms, trifluoromethyl $\left(\mathrm{CF}_{3}\right)$, trifluoromethylsulfanyl $\left(\mathrm{SCF}_{3}\right)$ and perfluoroalkyl groups $\left(\left(\mathrm{CF}_{2}\right)_{n} \mathrm{CF}_{3}\right)$ onto a carbon skeleton. ${ }^{3}$ Among these fluorine containing functional groups, the pentafluorosulfanyl $\left(\mathrm{SF}_{5}\right)$ group, also called as "supertrifluoromethyl group", is one of the emergent perfluorinated substituents. It displays unique and useful properties such as high electronegativity, high lipophilicity, an important steric hindrance, and high thermal and chemical stability. ${ }^{4}$ This pentafluorosulfanyl group has been introduced quite efficiently in biologically active compounds leading in some cases to interesting properties. $^{5}$ Compared to other fluorinated

Normandie Univ., COBRA, UMR 6014 \& FR 3038, Univ. Rouen, INSA Rouen, CNRS, 1 rue Tesnière, F-76821 Mont-Saint-Aignan Cedex, France. E-mail: jean-philippe. bouillon@univ-rouen.fr; philippe.jubault@insa-rouen.fr

$\dagger$ Electronic supplementary information (ESI) available: Experimental section and computational details. CCDC 1024823 and 1024824. For ESI and crystallographic data in CIF or other electronic format see DOI: 10.1039/c4ra14075c moieties, the introduction of $\mathrm{SF}_{5}$ group is less developed in the literature essentially because of the lack of efficient synthetic methods but also because few $\mathrm{SF}_{5}$-building blocks are described up to date. ${ }^{6}$ Very recently, we have reported ${ }^{7}$ a mild and efficient synthesis of new pentafluorosulfanyl-substituted acrylic esters 2 and amides 3 from 3-pentafluorosulfanyl-propenoic acids 1 (Scheme 1).

Having in hands these scaffolds, we were interested in their usefulness to access more valuable skeletons. 1,3-Dipolar cycloadditions which are described as involving a classical onestep mechanism, ${ }^{8 a}$ are a useful tool in organic synthesis. However, knowledge about these reactions has significantly evolved from the original concerted mechanism. Indeed, 1,3-dipolar cycloaddition reactions of thiocarbonyl ylides or (Z)-C,N-diphenylnitrone in the presence of strongly electrophilic dipolarophiles such as dimethyl 2,3-dicyanofumarate, ${ }^{9 a}$ gem1,1 -dinitroethene ${ }^{9 b}$ or $\alpha$-phenylnitroethene, ${ }^{9 c}$ were reported as two-steps processes through zwitterionic intermediates, leading to various heterocycles. Among them, five-membered nitrogen derivatives, especially the highly substituted pyrrolidines, are widely encountered in pharmaceuticals, natural alkaloids, organocatalysts, and are also very useful building blocks in synthetic organic chemistry. ${ }^{8 b, c}$ In particular, trifluoromethylated pyrrolidines have been efficiently synthetized using the 1,3-dipolar

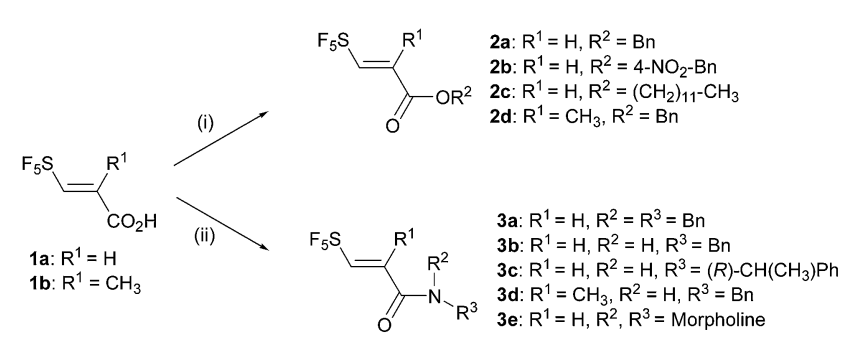

(i) $\mathrm{R}^{2} \mathrm{OH}$ (2 equiv.), $\mathrm{HOBt}$ (1.1 equiv.), DCC (2 equiv.), DMAP (1 equiv.), $\mathrm{CH}_{2} \mathrm{Cl}_{2}, 0^{\circ} \mathrm{C}$. (ii) $\mathrm{R}^{2} \mathrm{R}^{3} \mathrm{NH}$ (2 equiv.), $\mathrm{HOBt}$ (1.1 equiv.), DCC (2 equiv.), DMAP (1 equiv.), $\mathrm{CH}_{2} \mathrm{Cl}_{2}, 0^{\circ} \mathrm{C}$

Scheme 1 Synthesis of pentafluorosulfanyl-substituted esters 2 and amides 3 . 
cycloaddition of a non-stabilised azomethine ylide with electrodeficient alkenes (4,4,4-trifluorocrotonates) as initially reported by Bégué $e^{10 a, b}$ and then largely developed by Wang ${ }^{10 c, d}$ in an elegant catalytic enantioselective approach.

With our new type of electron-deficient alkenes, we were interested in studying the 1,3-dipolar cycloaddition of classical azomethine ylides with pentafluorosulfanyl-substituted acrylic esters 2 and amides 3 which could offer, for the first time, an efficient entry to $\mathrm{SF}_{5}$-substituted pyrrolidines.

Our initial studies began with the reaction of trans-benzyl pentafluorosulfanylacrylate 2a with $N$-(methoxymethyl)- $N$-[(trimethylsilyl)methyl]- $N$-benzylamine 4 in the presence of a catalytic amount of trifluoroacetic acid in dichloromethane (Scheme 2). To our delight, we obtained the expected $\mathrm{SF}_{5}$-pyrrolidine $5 \mathbf{a}$ in a good isolated yield (69\%). When the same conditions were applied to $\mathrm{SF}_{5}$-unsaturated amide $3 \mathbf{a}$, we did not observe a complete conversion (46\%). Using 2 equivalents of dipolarophile precursor 4 enabled the conversion to reach $96 \%$ and the pentafluorosulfanyl-substituted pyrrolidine $\mathbf{5 b}$ was isolated in $79 \%$ yield.

Under the above-described reaction conditions for the synthesis of $\mathrm{SF}_{5}$-pyrrolidines in each series, several pentafluorosulfanylated esters and amides were engaged in order to study the scope of the reaction (Fig. 1).

We demonstrated that 1,3-dipolar cycloaddition could be applied to various $\mathrm{SF}_{5}$-unsaturated esters, secondary and tertiary amides as well as chiral amide, leading to the expected pyrrolidines $\mathbf{5}$ in moderate to excellent isolated yields. Interestingly trisubstituted ester (2d) and amide (3d) (Scheme 1) reacted also to give the corresponding pyrrolidines (5e and $\mathbf{5 i}$ ) in moderate yields ( $46 \%$ and $36 \%$ respectively), probably due to the steric hindrance of the starting materials. It is worth noting that the reaction proved to be totally diastereoselective. Indeed, in all cases, starting from $(E)$ acrylates $\mathbf{2}$ or acrylamides $\mathbf{3}$, only the trans pyrrolidines were obtained, as racemic mixtures, except in the case of the product $5 \mathbf{g}$ which was obtained as a $1: 1$ mixture of trans diastereoisomers, which could be separated by silica gel column chromatography. Trans relationship between the two substituents was confirmed by X-ray diffraction analysis of pyrrolidine derivative $\mathbf{5 f} \mathbf{.}^{\mathbf{1 2}}$

After demonstrating that 1,3-dipolar cycloaddition occurred efficiently between $\mathrm{SF}_{5}$-dipolarophiles and precursor of azomethine ylide $\mathbf{4}$, we turned our attention to the use of

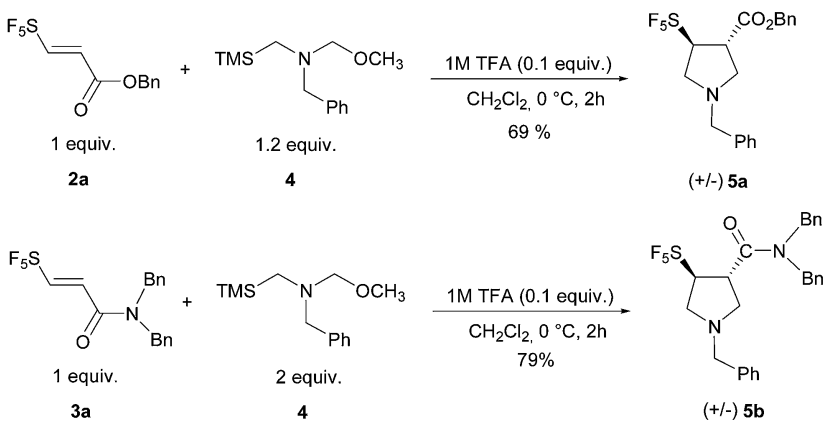

Scheme 2 Synthesis of pentafluorosulfanyl pyrrolidines $5 a$ and $5 b$.

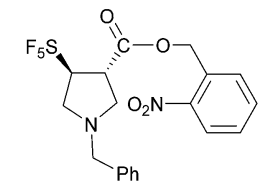

5c: $88 \%$

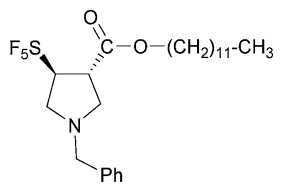

5d: $62 \%$

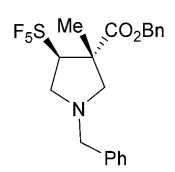

5e: $46 \%$

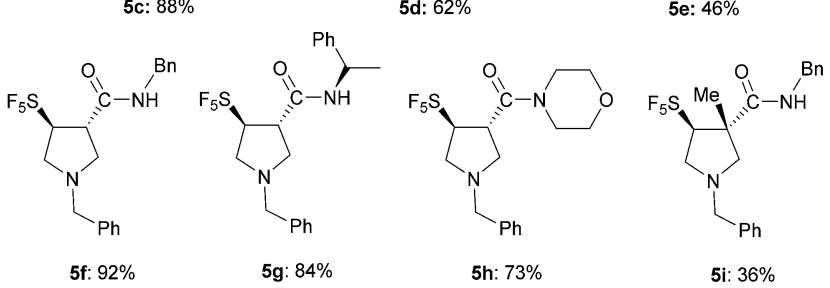

Fig. 1 Scope of the 1,3-dipolar cycloaddition using precursor 4 of azomethine ylide. ${ }^{11}$

$\mathrm{N}$-benzylidene glycine methyl ester $\mathbf{6}$ which could give us an access to tetrasubstituted $\mathrm{SF}_{5}$-pyrrolidines.

Our study began with the reaction of $\mathrm{SF}_{5}$-unsaturated ester 2a with glycine derivative 6 (1.7 equiv.) in the presence of $10 \mathrm{~mol} \% \mathrm{AgOAc} / \mathrm{PPh}_{3}$ and $15 \mathrm{~mol} \% \mathrm{Et}_{3} \mathrm{~N}$ at room temperature. A promising $40 \%$ yield of pyrrolidines $8+\mathbf{8}^{\prime}$ (Table 1 , entry 1 ), as a $1: 1$ mixture of two regioisomers, was obtained. By increasing the quantity of $\mathrm{AgOAc} / \mathrm{PPh}_{3}$ to $20 \mathrm{~mol} \%$ and $\mathrm{Et}_{3} \mathrm{~N}$ to $25 \mathrm{~mol} \%$, the expected pyrrolidines were obtained in $75 \%$ yield but in a quite long reaction time ( $90 \mathrm{~h}$, Table 1 , entry 2$)$. When allowed to warm to reflux, pyrrolidines 8 and $\mathbf{8}^{\prime}$ were obtained in $73 \%$ yield after $21 \mathrm{~h}$ (Table 1, entry 3). Stereochemistry of the products 8 and $\mathbf{8}^{\prime}$ was elucidated based on NOESY experiments and was independently confirmed by the X-ray analysis in the case of $\mathbf{8 .}^{\mathbf{2}}$

Two major differences appeared concerning the cycloaddition of this dipole precursor 6 in the $\mathrm{SF}_{5}$-series compared to the previously reported $\mathrm{CF}_{3}$-ones. ${ }^{\mathbf{1 0 a}}$ The first one concerns the kinetic of the reaction which is much slower $(21 \mathrm{~h}$ in refluxed dichloromethane) with 2 a compared to the one observed using the $\mathrm{CF}_{3}$ analog ( $5 \mathrm{~h}$ at room temperature). The second one is the regiochemistry. Indeed, in the $\mathrm{CF}_{3}$ series, the reaction was almost totally regioselective $(\mathrm{dr}>98: 2)$ whereas a $1: 1$ mixture of regioisomers $\mathbf{8}+\mathbf{8}^{\prime}$ was obtained using $\mathbf{2 a}$. When $2 \mathbf{a}$ was reacted with dipole precursor 7 (entry 4), only 55\% conversion of $\mathrm{SF}_{5}$-derivatives was observed after $21 \mathrm{~h}$. Longer reaction times led to degradation of the expected pyrrolidines $9+\mathbf{9}^{\prime}$. When $\mathrm{SF}_{5}-$ amide $3 \mathbf{e}$ was engaged in the cycloaddition reaction with $\mathbf{6}$, a lower yield of $10+10^{\prime}$ (48\%, entry 5 ) was observed compared to the one during the reaction with $\mathrm{SF}_{5}$-ester $2 \mathbf{a}$ (entry 3 ).

Theoretical calculations were then carried out in order to cast light on the factors governing the observed regiochemistry. To this aim, three theories were combined, all based on the primary quantum observable (the electron density), namely DFT (to determine the mechanism), conceptual DFT (to characterize reactive behaviours), and Bader's theory (QTAIM) (to quantify interactions). ${ }^{13}$ Three model systems 11-13 (Scheme 3) were investigated: unsaturated $\mathrm{CF}_{3}$ - and $\mathrm{SF}_{5}$-esters and the corresponding $\mathrm{SF}_{5}$-amide, considering the imine forms a complex with $\mathrm{AgPMe}_{3}{ }^{+}\left(\Delta G_{\text {form }}^{\circ}=-22 \mathrm{kcal} \mathrm{mol}^{-1}\right)$. 
Table 1 Study of optimal conditions for 1,3-dipolar cycloaddition with imino ester 6 or 7

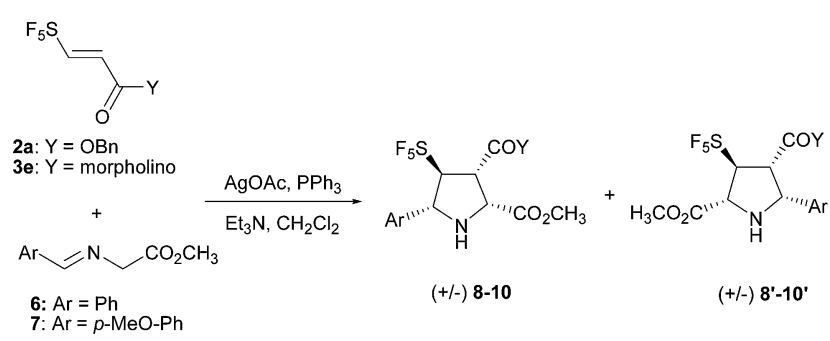

\begin{tabular}{|c|c|c|c|c|c|c|}
\hline Entry & $\mathrm{SF}_{5}$-derivative & 6 or 7 (equiv.) & $\mathrm{AgOAc}(\mathrm{mol} \%)$ & $\mathrm{PPh}_{3}(\mathrm{~mol} \%)$ & Time (h) & Yield $^{a}(\%)$ \\
\hline $1^{c}$ & $2 a$ & $6(1.7)$ & 10 & 10 & $17^{e}$ & $40(1: 1)^{b}$ \\
\hline $2^{d}$ & $2 a$ & $6(3)$ & 20 & 20 & $90^{e}$ & $75(1: 1)^{b}$ \\
\hline $4^{d}$ & $2 a$ & $7(3)$ & 20 & 20 & $21^{f, g}$ & $35(2: 1)^{b}$ \\
\hline $5^{d}$ & $3 e$ & $6(3)$ & 20 & 20 & $21^{f, g}$ & $48(1: 1.5)^{b}$ \\
\hline
\end{tabular}

${ }^{a}$ Global isolated yield of regioisomers. ${ }^{b}$ Ratio of regioisomers. ${ }^{c} 0.15$ equiv. of $\mathrm{Et}_{3} \mathrm{~N}$. ${ }^{d} 0.25$ equiv. of Et ${ }_{3} \mathrm{~N} .{ }^{e}$ Room temperature. $^{f} \mathrm{Reflux}$

${ }^{g}$ Conv. $\sim 55 \%$.

The first step is the formation of a non-covalent adduct (without noticeable global electron charge transfer) ${ }^{\mathbf{1 4}}$ between the two reaction partners. For each model compound, six different orientations were studied, as depicted in Fig. S1 (see ESI $\dagger$ ). They are classified according to the corresponding regiochemistry, the relative positions of the substituents, as well as the $s$-cis or $s$-trans possible isomerization (Table S1, ESI $\dagger$ ). This adducts formation (that is also encountered in other cycloaddition reactions) ${ }^{15}$ can be qualitatively rationalized in the framework of conceptual DFT (using the recently developed first-state specific dual descriptor) ${ }^{16}$ which shows the nucleophilic regions coming on top of the electrophilic areas. It also appeared that the most nucleophilic carbon atom on the imine moiety is that linked to the methoxycarbonyl substituent (Fig. S2, ESI $\dagger$ ).

The formation of the $\mathrm{C}-\mathrm{C}$ bonds can be then completed, a dichotomy being revealed by both static and dynamical approaches (see Graphs S1-S4, Fig. S3, ESI $\dagger$ ): the pentacycle formation can occur in one step that is highly asynchronous (the process can thus be viewed as "one-step - two-stage") ${ }^{17}$ as evinced by the reaction force profile, ${ }^{18}$ or in two unconcerted steps. As deduced from Table S2 (ESI $\dagger$ ), the most thermodynamically stable products do not correspond to the experimentally obtained ones, suggesting that these reactions are ruled by kinetic control. Indeed, in terms of the lowest $\Delta G^{\circ}$
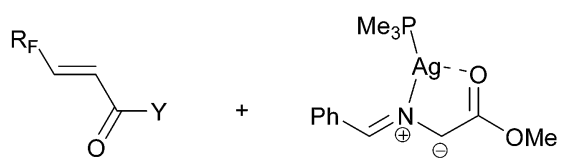

11: $Y=O M e, R_{F}=C_{3}$

12: $\mathrm{Y}=\mathrm{OMe}, \mathrm{R}_{\mathrm{F}}=\mathrm{SF}_{5}$

13: $\mathrm{Y}=\mathrm{NMe}_{2}, \mathrm{R}_{\mathrm{F}}=\mathrm{SF}_{5}$

Scheme 3 Model systems 11-13 for the theoretical study. activation barriers, the observed regiochemistry is retrieved, the following hierarchy emerging: $\mathrm{CF}_{3}$-ester $\left(\approx 11 \mathrm{kcal} \mathrm{mol}^{-1}\right)$ $<\mathrm{SF}_{5}$-ester $\left(12 \mathrm{kcal} \mathrm{mol}^{-1}\right)<\mathrm{SF}_{5}$-amide $\left(13 \mathrm{kcal} \mathrm{mol}^{-1}\right)$, the cycloaddition with $\mathrm{SF}_{5}$-derivatives being slower, as experimentally observed.

Finally, in order to disentangle the main physicochemical properties involved in this regiochemistry, a detailed energetic decomposition (eqn S6, ESI $\dagger$ ) was performed for the most favoured approaches. The first striking point is that the reaction is spontaneous from an electronic energy viewpoint (Fig. 2: all $\Delta E_{\text {Solv }}<0$ ) because of the important adduct stabilities. Besides (see Fig. 2), $\Delta E_{\text {Solv }}$ predicts the regiochemistry described in path 1 to be univocally favoured. Such results differ from those obtained from Gibbs energies, notably because the overall activation energy is actually the sum of the adduct destabilization and the TS activation energy itself.

From Table S3 (ESI $\dagger$ ), it could be inferred that the highest contribution in absolute value stems from the adducts' nonvibrational entropy. However it cannot account for regiochemistry, at variance with the electronic stabilization energy of the adduct $\left(E_{\text {add }}\right)$, the electronic activation barrier $\left(E_{\text {act }}\right)$ from the

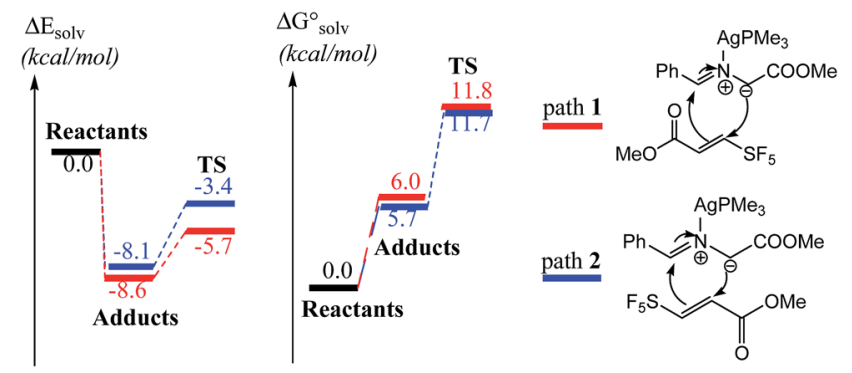

Fig. 2 Regiochemistry according to $\Delta E_{\text {Solv }}$ and $\Delta G_{\text {Solv }}^{\circ}$ viewpoints for the $\mathrm{SF}_{5}$-ester compound 12 . 
adduct, and the vibrational entropies of both adduct and TS. $E_{\text {add }}$ favours path 1 in the ester cases and path 2 for amide and is correctly predicted by the preference dual descriptor ${ }^{19}$ (Graph $\mathrm{S} 5, \mathrm{ESI} \dagger)$. $\mathrm{E}_{\text {act }}$ is lower for path 1 in any case, a result that can be explained using QTAIM (by focusing on local critical point properties, Graph S6, ESI $\dagger$ ). As for entropy effects (see Graph S7, $\mathrm{ESI} \dagger$ ), we epitomize their role for the $\mathrm{SF}_{5}$-ester 12: the vibrational entropy change from the adduct to the TS is $2.1 \mathrm{kcal}$ $\mathrm{mol}^{-1}$ more destabilizing in path 1 than in path 2 , effectively counterbalancing the pure electronic features. As a consequence, a mixture of regioisomers is expected in the $\mathrm{SF}_{5}$-series.

Lastly, one can wonder whether $\mathrm{Ag}\left(\mathrm{PMe}_{3}\right)^{+}$may have a catalytic effect. The corresponding activation barriers without it are actually slightly lower (8.4 and $7.4 \mathrm{kcal} \mathrm{mol}^{-1}$ for the $\mathrm{CF}_{3}-(\mathbf{1 1})$ and $\mathrm{SF}_{5}$-esters (12), respectively), so that the main role of the AgOAc and $\mathrm{PPh}_{3}$ combination may be assumed (at the retained theoretical model) to concern precursor deprotonation.

\section{Conclusions}

In conclusion, a straightforward single step procedure for the preparation of $\mathrm{SF}_{5}$-substituted pyrrolidines using pentafluorosulfanyl-substituted acrylic esters and amides was developed. Moreover, a convergent DFT-Conceptual DFT-QTAIM theoretical strategy was defined and applied to unravel the main factors accounting for the observed regiochemistry. Further developments especially devoted to an asymmetric version of this 1,3-dipolar cycloaddition process are currently under investigation in our laboratory. This approach can also be further used for the synthesis of $\mathrm{SF}_{5}$-analogues of biorelevant molecules.

\section{Acknowledgements}

This work was financially supported by MESR (Ministère de l'Enseignement Supérieur et de la Recherche), the Région Haute-Normandie (CRUNCh program), CNRS, Rouen University, INSA of Rouen and Labex SynOrg (ANR-11-LABX-0029). The CRIHAN is acknowledged for computational resources. The authors also thank Pr. H. Oulyadi and L. Truong for NOESY experiments.

\section{Notes and references}

1 For general reviews, see:(a) J. T. Welch, S. Eswarakrishnan, Fluorine in Bioorganic Chemistry, Wiley, New York, 1991; (b) K. Burger, U. Wucherpfennig and E. Brunner, $A d v$. Heterocycl. Chem., 1994, 60, 1; (c) N. C. Yoder and K. Kumar, Chem. Soc. Rev., 2002, 31, 335; (d) C. Jackel and B. Koksch, Eur. J. Org. Chem., 2005, 335; (e) S. Purser, P. R. Moore, S. Swallow and V. Gouverneur, Chem. Soc. Rev., 2008, 37, 320; (f) J.-P. Bégué, D. Bonnet-Delpon, Bioorganic and Medicinal Chemistry of Fluorine, Wiley-VCH, Weinheim, 2008; (g) W. K. Hagmann, J. Med. Chem., 2008, 51, 4359; (h) K. L. Kirk, Org. Process Res. Dev., 2008, 12, 305; (i) R. Gilmour and D. Seebach, Chimia, 2014, 68, 345; (j) J. Wang, M. Sanchez-Rosello, J. L. Acena, C. del Pozo,
A. E. Sorochinsky, S. Fustero, V. A. Soloshonok and H. Liu, Chem. Rev., 2014, 114, 2432.

2 Fluorine in Medicinal Chemistry and Chemical Biology, ed. I. Ojima, Wiley-Blackwell, New York, 2009.

3 For recent reviews of fluorination, see:(a) H. Amii and K. Uneyama, Chem. Rev., 2009, 109, 2119; (b) N. Al-Maharik and D. O'Hagan, Aldrichimica Acta, 2011, 44, 65; (c) T. Liang, C. N. Neumann and T. Ritter, Angew. Chem., Int. Ed., 2013, 52, 8214; (d) V. Bizet, T. Besset, J.-A. Ma and D. Cahard, Curr. Top. Med. Chem., 2014, 14, 901. For recent reviews of trifluoromethylation, see:; (e) J.-A. Ma and D. Cahard, J. Fluorine Chem., 2007, 128, 975; $(f)$ S. Roy, B. T. Gregg, G. W. Gribble, V.-D. Le and S. Roy, Tetrahedron, 2011, 67, 2161; $(g)$ T. Besset, C. Schneider and D. Cahard, Angew. Chem., Int. Ed., 2012, 51, 5048; (h) H. Liu, Z. Gu and X. Jiang, Adv. Synth. Catal., 2013, 355, 617; (i) H. Egami and M. Sodeoka, Angew. Chem., Int. Ed., 2014, 53, 8294. For recent review of trifluoromethylthiolation, see:; $(j)$ S. Alazet, L. Zimmer and T. Billard, Chem.-Eur. J., 2014, 20, 1; (k) F. Toulgoat, S. Alazet and T. Billard, Eur. J. Org. Chem., 2014, 2415; (l) X.-H. Xu, K. Matsuzaki and N. Shibata, Chem. Rev., 2014, DOI: $10.1021 / \mathrm{cr} 500193 \mathrm{~b}$. For recent reviews of perfluoroalkylation, see:; $(m)$ Y. Macé and E. Magnier, Eur. J. Org. Chem., 2012, 2479; (n) G. Landelle, A. Panossian, S. Pazenok, J.-P. Vors and F. R. Leroux, Beilstein J. Org. Chem., 2013, 9, 2476; (o) T. Besset, T. Poisson and X. Pannecoucke, Chem.-Eur. J., 2014, 20, 16830.

4 (a) P. Kirsch, Modern Fluoroorganic Chemistry, Wiley-VCH, Weinheim, 2nd edn, 2013; (b) P. Wipf, T. Mo, S. J. Geib, D. Caridha, G. S. Dow, L. Gerena, N. Roncal and E. E. Milner, Org. Biomol. Chem., 2009, 7, 4163; (c) S. Altomonte and M. Zanda, J. Fluorine Chem., 2012, 143, 57; (d) P. R. Savoie and J. T. Welch, Chem. Rev., 2014, DOI: 10.1021/cr500336u.

5 (a) B. Stump, C. Eberle, W. B. Schweizer, M. Kaiser, R. Brun, R. L. Krauth-Siegel, D. Lentz and F. Diederich, ChemBioChem, 2009, 10, 79; (b) J. M. Coteron, M. Marco, J. Esquivias, X. Deng, K. L. White, J. White, M. Koltun, F. E. Mazouni, S. Kokkonda, K. Katneni, R. Bhamidipati, D. M. Shakleford, I. Angulo-Barturen, B. S. Ferrer, M. B. Jimenez-Diaz, F.-J. Gamo, E. J. Goldsmith, W. N. Charman, I. Bathurst, D. Floyd, D. Matthews, J. N. Burrows, P. D. Rathod, S. A. Charman and M. A. Phillips, J. Med. Chem., 2011, 54, 5540; (c) J. T. Welch and D. S. Lim, Bioorg. Med. Chem., 2007, 15, 6659; (d) W. R. Dolbier and Z. Zeng, J. Org. Chem., 2009, 74, 5626; (e) T. Mo, X. Mi, E. E. Milner, G. S. Dow and P. Wipf, Tetrahedron Lett., 2010, 51, 5137.

6 (a) G. L. Gard, J. Fluorine Chem., 2009, 27, 10; (b) T. Umemoto, L. M. Garrick and N. Saito, Beilstein J. Org. Chem., 2012, 8, 461; (c) A. V. Matsev, S.-Y. Qing, M. A. Stanton, K. A. Berger, G. Haufe and J. S. Thrasher, Org. Lett., 2014, 16, 2402; (d) G. L. Gard and R. Winter, J. Fluorine Chem., 1994, 66, 109; (e) W. S. Husstedt, J. S. Thrasher and G. Haufe, Synlett, 2011, 183; $(f)$ I. V. Trushkov and V. K. Brel, Tetrahedron Lett., 2005, 46, 
4777; (g) V. K. Brel, Synthesis, 2006, 339; (h) R. W. Winter, D. Dodean and G. L. Gard, J. Fluorine Chem., 2004, 125, 37;

(i) V. K. Brel, J. Fluorine Chem., 2007, 128, 862; (j) M. Berger, C. Kern, M. Eck and J. Schroeder, PCT Int. Appl., 2012, WO2012041872; (k) M. V. Ponomarenko, Y. A. Serguchev and G.-V. Roschenthaler, Synthesis, 2010, 3906; ( $l$ ) A. Joliton and E. M. Carreira, Org. Lett., 2013, 15, 5147; $(m)$ N. Vida, T. Pastyrikova, B. Klepetarova and P. Beier, J. Org. Chem., 2014, 79, 8906.

7 E. Falkowska, F. Suzenet, P. Jubault, J.-P. Bouillon and X. Pannecoucke, Tetrahedron Lett., 2014, 55, 4833.

8 (a) L. M. Harwood, R. J. Vickers, In Synthetic Applications of 1,3-Dipolar Cycloaddition Chemistry toward Heterocycles and Natural Products, ed. A. Padwa and W. Pearson, Wiley \& Sons, New York, 2002; (b) J.-P. Michael, Nat. Prod. Rep., 2008, 25, 139; (c) M.-Y. Han, J.-Y. Jia and W. Wang, Tetrahedron Lett., 2014, 55, 784.

9 (a) R. Huisgen, G. Mloston and E. Langhals, J. Am. Chem. Soc., 1986, 108, 6401; (b) R. Jasiński, Tetrahedron, 2013, 69, 927; (c) R. Jasiński, M. Mikulska and A. Barański, Cent. Eur. J. Chem., 2013, 11, 404.

10 (a) J.-P. Bégué, D. Bonnet-Delpon and T. Lequeux, Tetrahedron Lett., 1993, 34, 3279; (b) J.-P. Bégué, D. BonnetDelpon, A. Chennoufi, M. Ourévitch, K. S. Ravikumar and A. H. Rock, J. Fluorine Chem., 2001, 107, 275; (c) Q.-H. Li, M.-C. Tong, J. Li, H.-Y. Tao and C.-J. Wang, Chem. Commun., 2011, 47, 11110; (d) Q.-H. Li, Z.-Y. Xue, H.-Y. Tao and C.-J. Wang, Tetrahedron Lett., 2012, 53, 3650.

11 Using $\mathrm{PMB}$ analogue of 4 and $\mathrm{SF}_{5}$-ester $\mathbf{2 a}$, pyrrolidine $5 \mathbf{j}$ was obtained in $66 \%$ yield. Using PMB analogue of 4 and
$\mathrm{SF}_{5}$-ester 2c, pyrrolidine $\mathbf{5 k}$ was obtained in $46 \%$ yield. When the cycloaddition reaction was carried out between $\mathrm{SF}_{5} \mathrm{CH}=\mathrm{CH}-\mathrm{CH}_{2} \mathrm{OAc}$ and dipole precursor 4 (same conditions as described in Scheme 2), pyrrolidine $\mathbf{5 l}$ was obtained in $61 \%$ yield.

12 X-ray crystal structure determinations. $\dagger$

13 For an overview on conceptual DFT, see: (a) P. Geerlings, F. de Proft and W. Langenaecker, Chem. Rev., 2003, 103, 1793, and for QTAIM, see: $(b)$ R. F. W. Bader, Atoms in molecules: a quantum theory, Oxford University Press, Oxford UK, 1990.

14 L. R. Domingo, RSC Adv., 2014, 4, 32415.

15 (a) R. Jasiński, O. I. Koifmanb and A. Barański, Mendeleev Commun., 2011, 21, 262; (b) R. Jasiński, K. Wasik, M. Mikulska and A. Barański, J. Phys. Org. Chem., 2009, 22, 717; (c) V. Tognetti, P. Cortona and C. Adamo, Theor. Chem. Acc., 2009, 122, 257.

16 (a) V. Tognetti, C. Morell, P. W. Ayers, L. Joubert and H. Chermette, Phys. Chem. Chem. Phys., 2013, 15, 14465; (b) F. Guégan, P. Mignon, V. Tognetti, L. Joubert and C. Morell, Phys. Chem. Chem. Phys., 2014, 16, 15558.

17 (a) L. R. Domingo and J. A. Sáez, Org. Biomol. Chem., 2009, 7, 3576; (b) R. Jasiński, M. Ziółkowska, O. M. Demchuk and A. Maziarka, Cent. Eur. J. Chem., 2014, 12, 586.

18 (a) A. Toro-Labbé, J. Phys. Chem. A, 1999, 103, 4398; (b) V. Labet, C. Morell, A. Toro-Labbé and A. Grand, Phys. Chem. Chem. Phys., 2010, 12, 4142.

19 L.-A. Jouanno, V. Di Mascio, V. Tognetti, L. Joubert, C. Sabot and P.-Y. Renard, J. Org. Chem., 2014, 79, 1303. 